\title{
"Biology of the Eye," A Novel Multiformat Translational Elective for Medical Students
}

\author{
A. Itzam Marin, BS ${ }^{1} \quad$ Joseph A. Brzezinski IV, $\mathrm{PhD}^{1} \quad$ Ram Nagaraj, $\mathrm{PhD}^{1} \quad$ Jasleen K. Singh, MD ${ }^{1}$ \\ ${ }^{1}$ Department of Ophthalmology, University of Colorado School of \\ Medicine, Aurora, Colorado \\ J Acad Ophthalmol 2019;11:e30-e35. \\ Address for correspondence Jasleen K. Singh, MD, Department of \\ Ophthalmology, University of Colorado School of Medicine, 13123 \\ East, 16th Avenue, B430. Aurora, CO 80045 \\ (e-mail: Jasleen.singh@ucdenver.edu).
}

\begin{abstract}
Keywords

- ophthalmology

- undergraduate medical education

- curriculum development

- medical school curriculum

Objective To allow medical undergraduate students an exposure to ophthalmology in the preclinical years as well as introduce concepts of basic and clinical science in ophthalmology for medical students.

Methods The 10-session elective was offered to 2 nd year medical students in the fall of 2016 and to 1 st and 2nd year medical students in the fall of 2017 at the University of Colorado School of Medicine. The curriculum included a dissection laboratory, lectures, and journal reviews of key topics in ophthalmology with a basic scientist and clinician. At the conclusion of the sessions, the students evaluated this course by survey.

Results Six medical students participated in the fall of 2016 and 11 students in the fall of 2017 . The response rate was 83.33 and $100 \%$, respectively. On a five- point Likert's scale, the students in both fall 2016 and 2017 rated the course as 4.7, indicating a positive reaction. Quality of learning objectives was rated as 4.4 and 4.5 in 2016 and 2017, respectively. Course management had a score of 4.4 and 4.6 in 2016 and 2017, respectively. Comments included: "I learned a lot about the eye I would not have known if I had not taken the course," "I enjoyed the interplay between the clinical and basic science experts," and "I liked the model of learning about a subject then looking at the research [sic]."

Conclusions Based on the students' responses and level of satisfaction, we concluded that the elective course was successful at increasing medical students' exposure to ophthalmology at the University of Colorado School of Medicine while incorporating both basic and clinical science. Based on review of the students' feedback, modifications to the course included, expanding the course to 1 st year medical students, limiting presentation times, simplifying presentation topics, and adding worksheets to guide article review sessions.
\end{abstract}

The evolution of the medical field has created a medical school curriculum that is extremely saturated. This has led to a reduction of lecture time and clinical exposure in some topics, with ophthalmology and eye pathology being markedly affected. ${ }^{1-3}$ Despite eye conditions being ubiquitous in primary care and other core specialties, fundamental ophthalmologic education in medical school has decreased dramatically in the last four decades. ${ }^{2,4}$ Meanwhile, the number of medical schools requiring ophthalmology rotations continues to decline. ${ }^{1,5}$ The reduction in ophthalmology education has also been linked to primary care physicians feeling that they were inadequately trained to perform essential eye examination skills. ${ }^{6,7}$ Since our aging population will increase the prevalence of several eye diseases, it is imperative to educate future physicians about proper diagnosis, early management, and referral for conditions such as glaucoma, cataracts, macular degeneration, and received

November 4, 2018

accepted after revision

March 22, 2019
DOI https://doi.org/

10.1055/s-0039-1688761.

ISSN 2475-4757.
Copyright (C 2019 by Thieme Medical Publishers, Inc., 333 Seventh Avenue, New York, NY 10001, USA. Tel: +1(212) 584-4662
License terms

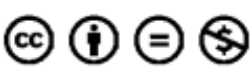


diabetic retinopathy. ${ }^{7}$ To address the needs of our patients, it is important to maintain a sustainable curriculum that can efficiently educate future primary care providers to properly identify these disorders.

The lack of exposure to ophthalmology in medical school may limit the contemplation of ophthalmology as a career option. Different studies have shown that exposure to ophthalmology in the preclinical and clinical years not only enhances medical students' examination skills but also increases their interest to pursue a career in Ophthalmology. ${ }^{2,6,8-10}$ Additionally, despite the limited ophthalmology exposure in the medical school curriculum, the San Francisco Match requires medical students to decide earlier if they want to pursue ophthalmology as a career. All these factors make the early exposure to the ophthalmology field a key milestone in the recruitment of future ophthalmologists, as well as in the training of future primary care providers as gatekeepers of health care.

Despite the advantages of early exposure, how to integrate ophthalmology into medical school curriculum has been a challenge. The use of conventional lectures, rotations, and small groups has shown limited success. ${ }^{11}$ In fields like neurosurgery, the use of preclinical multimodal electives including small group discussions and clinical exposure, have proven to enhance students' interest acutely and over long-term as measured by a 6 -year follow-up. ${ }^{12,13}$

The University of Colorado School of Medicine (CUSOM) offers voluntary courses to aid in career exploration, diversify interests, and supplement knowledge of required courses from the core curriculum. CUSOM offers around 50 different electives to 1 st and 2nd year medical students. These courses are entirely voluntary and there is no specific minimum or maximum to the number of electives that students can take. However, due to their usefulness for career exploration a good rule of thumb for the number of electives to take is one to two elective courses each semester throughout the medical school curriculum. They comprise a broad range of topics including: medical Spanish, cancer biology, emergency medicine, culinary medicine, and art medicine.

Here, we present the evaluations and feedback of our optional multiformat elective course entitled: "Biology of the Eye." To bridge the gap between basic and clinical sciences, the curriculum of our elective consisted of a combination of three different teaching formats including (1) a hands-on dissection laboratory, (2) lectures followed by discussion, and (3) journal article review of key topics in ophthalmology with a basic scientist and clinician. The goals of this course were to increase exposure of medical students to ophthalmology compared with the traditional curriculum, to provide a safe platform for career discussions and mentorship, and to inspire a career path as a clinician scientist in the field of ophthalmology.

\section{Methods}

\section{Class Formatting}

In the fall semesters of 2016 and 2017, an integrative ophthalmology elective course was offered by clinical and basic science faculty of the Department of Ophthalmology at the
University of Colorado. The 6-week elective was offered to $1 \mathrm{st}$ and 2 nd year medical students, mirroring the courses during preclinical years. The elective consisted in a total of 10 sessions including three different lecture formats; (1) anatomy and hands-on eye dissection, (2) lectures, and (3) journal article discussions. A course syllabus with details including sessionspecific learning objectives is shown in - Table 1. The class started with a 2-hour wet laboratory anatomy class session. Lecture classes consisted of six 60-minute sessions. The lecture

Table 12017 Course syllabus

\begin{tabular}{|c|c|}
\hline Topic & Learning objectives \\
\hline $\begin{array}{l}\text { Eye gross anatomy } \\
\text { and wet laboratory } \\
\text { session }\end{array}$ & $\begin{array}{l}\text { 1. To identify the major anatomical } \\
\text { features of the eye in a hands-on } \\
\text { fashion. }\end{array}$ \\
\hline Lens & $\begin{array}{l}\text { 1. To learn the basic structure, develop- } \\
\text { ment, and function of the lens. } \\
\text { 2. To understand lens aging and } \\
\text { age-related cataracts and new } \\
\text { strategies for their treatment. } \\
\text { 3. Molecular basis for inherited cataracts } \\
\text { and lens defects associated with } \\
\text { metabolic disease. }\end{array}$ \\
\hline Cornea & $\begin{array}{l}\text { 1. To identify the basic structure, devel- } \\
\text { opment, and function of the cornea. } \\
\text { 2. To become acquainted with common } \\
\text { corneal diseases and treatments. } \\
\text { 3. To understand the basic properties and } \\
\text { uses of limbal stem cells. }\end{array}$ \\
\hline $\begin{array}{l}\text { Lens and cornea } \\
\text { discussion section }\end{array}$ & $\begin{array}{l}\text { 1. To critically analyze contemporary } \\
\text { primary literature concerning the lens } \\
\text { and cornea. }\end{array}$ \\
\hline Retina I & $\begin{array}{l}\text { 1. To learn the basic structure, develop- } \\
\text { ment, and function of the retina and } \\
\text { retinal pigmented epithelium. } \\
\text { 2. To become acquainted with inherited } \\
\text { diseases of the retina and associated } \\
\text { tissues. } \\
\text { 3. To understand genotype-phenotype } \\
\text { relationships in diseased retinas. }\end{array}$ \\
\hline Retina II & $\begin{array}{l}\text { 1. To understand the etiology and } \\
\text { features of common age-related } \\
\text { retinal diseases. } \\
\text { 2. To identify therapeutic barriers and } \\
\text { novel treatment strategies for retinal } \\
\text { diseases. }\end{array}$ \\
\hline $\begin{array}{l}\text { Retina } \\
\text { discussion } \\
\text { section }\end{array}$ & $\begin{array}{l}\text { 1. To critically analyze primary literature } \\
\text { for current topics in retinal biology. }\end{array}$ \\
\hline Glaucoma & $\begin{array}{l}\text { 1. To understand the structure and } \\
\text { function of the ocular outflow system. } \\
\text { 2. To identify the etiology and } \\
\text { characteristics of glaucoma. } \\
\text { 3. To become acquainted with } \\
\text { therapeutic strategies for glaucoma. }\end{array}$ \\
\hline $\begin{array}{l}\text { Glaucoma } \\
\text { discussion } \\
\text { section }\end{array}$ & $\begin{array}{l}\text { 1. To critically analyze contemporary } \\
\text { primary literature in glaucoma. }\end{array}$ \\
\hline $\begin{array}{l}\text { Immunology } \\
\text { and the visual } \\
\text { system }\end{array}$ & $\begin{array}{l}\text { 1. To identify the role of the immune } \\
\text { system in ocular homeostasis and } \\
\text { stress states. } \\
\text { 2. To become familiar with inflammatory } \\
\text { processes in the eye. }\end{array}$ \\
\hline
\end{tabular}


topics covered lens, cornea, retina, glaucoma, and immunology of the visual system. These topics were chosen to cover common ocular diseases that faculty deemed as important. In addition, the topics included in the course were corroborated by recommendations of the Association of University Professors of Ophthalmology. Throughout the course, emphasis was placed on in-class participation. The journal discussion sessions consisted of three 80-minute discussion classes, where students evaluated and dissected one to two primary literature articles mirroring the material learned from the corresponding lecture. An example of the journal articles used can be illustrated by the article written by Lin et al, titled "Lens Regeneration Using Endogenous Stem Cells with Gain of Visual Function." ${ }^{14}$ The use of journal articles was aimed to incorporate both basic and clinical sciences content into practice by guiding students through the process of critical evaluation of current research. Additionally, the journal discussion sessions were meant to provide a platform for students to build mentorship relationships with clinician-scientists in the field.

\section{Recruitment}

This course was listed in the course catalog provided to all medical students. Additional recruitment of students was performed in the electives fair and by sending reminder emails to students that demonstrated interest through the ophthalmology interest group. Individual student communication with ophthalmology faculty was also used to provide course information to interested students.

\section{Attendance}

Attendance was mandatory and in case of absence, a 1- to 3page review summarizing missed topic/discussion papers was required. After -hour-scheduling of the elective course was done to allow students to attend sessions on top of their required medical school curriculum.

\section{Evaluation}

After conclusion of the elective, the students were invited to complete an anonymous evaluation form via Web site (-Table 2). The Office of Evaluation of the School of Medicine was in charge of creating and distributing student assessment and course evaluation forms for all courses in the University of Colorado School of Medicine. The survey consisted on a five-point Likert's scale used for each of the four quantitative questions evaluating the program on course quality, learning objectives, course management, and overall rating, with " 5 " representing the most positive choice. Each question was allotted with a free-response comment section. Additional free-comment questions without five-point Likert's scale included: areas where the course could be improved, whether students would recommend the course to peers interested in ophthalmology, effectiveness of wet laboratory and discussion sessions, and whether the course increased the student's own knowledge and excitement about ophthalmology research and clinical practices. To better interpret our subjective data, we further identified five categories based on common themes found on the students' responses to the free-comment questions from

Table 2 Biology of the eye-survey given to students at the end of the elective course

\begin{tabular}{|c|c|}
\hline & Please circle one answer. \\
\hline $\begin{array}{l}\text { Course Management } \\
\text { 1. On a scale of } 1 \text { to } 5 \text {, }\end{array}$ & $\begin{array}{l}\text { 1. (Completely NOT SATISFIED) } \\
\text { 2. (Not satisfied) } \\
\text { 3. (neither satisfied nor unsatisfied) } \\
\text { 4. (Satisfied) } \\
\text { 5. (Completely SATISFIED) }\end{array}$ \\
\hline 2. Comments on course management: & Comments: \\
\hline $\begin{array}{l}\text { Learning objectives } \\
\text { 3. On a scale of } 1 \text { to } 5 \text {, }\end{array}$ & $\begin{array}{l}\text { 1. (Very poor quality) } \\
\text { 2. (Poor quality) } \\
\text { 3. (Average quality) } \\
\text { 4. (High quality) } \\
\text { 5. (Very high quality) }\end{array}$ \\
\hline 4. Comments on learning objectives: & Comments: \\
\hline $\begin{array}{l}\text { Overall course quality } \\
5 . \text { On a scale of } 1 \text { to } 5 \text {, }\end{array}$ & $\begin{array}{l}\text { 1. (Very poor quality) } \\
\text { 2. (Poor quality) } \\
\text { 3. (Average quality) } \\
\text { 4. (High quality) } \\
\text { 5. (Very high quality) }\end{array}$ \\
\hline 6. Comments on overall course quality. & Comments: \\
\hline 7. Areas where the course could be improved. & Comments: \\
\hline $\begin{array}{l}\text { 8. Please comment on whether you would recommend this course to your } \\
\text { peers interested in ophthalmology. }\end{array}$ & Comments: \\
\hline $\begin{array}{l}\text { 9. Please comment on whether this course has increased your knowledge } \\
\text { and excitement about ophthalmology research and clinical practice. }\end{array}$ & Comments: \\
\hline $\begin{array}{l}\text { 10. Please comment on the effectiveness of the wet laboratory and } \\
\text { discussion sessions of the course. }\end{array}$ & Comments: \\
\hline
\end{tabular}


both fall 2016 and 2017. These included, general recommendations for the course, comments on the curriculum content, wet laboratory session comment, journal discussion sessions comments, and comments on the combination of basic and clinical science of our course.

\section{Results}

Six 2nd year medical students enrolled in the fall of 2016. In the fall of 2017, a total of 11 students were enrolled to the course (three 1 st year and eight 2 nd year medical students). A total of $100 \%$ students completed the course requirements.

\section{Likert Survey Questions}

The survey response rate in the fall of 2016 was $83.33 \%$ (fivesixth) and $100 \%$ (11/11) in the fall of 2017 . The $100 \%$ students who responded the survey completed the five-point Likert's scale questions plus the free-response questions. On the fivepoint Likert's scale, the students in both fall 2016 and 2017 rated the course as 4.7 (overall mean based on individual lectures, course management, learning objectives, and course quality), indicating a positive reaction. Quality of learning objectives was $=4.4$ (range: $3-5$ ) and $=4.5$ (range: 3-5) in 2016 and 2017, respectively. Course management had a score of $=4.4$ (range: $4-5$ ) and $=4.6$ (range: $3-$ 5) in 2016 and 2017, respectively.

\section{Qualitative Survey Questions}

In 2016 and 2017, 100\% of responding students indicated that the course increased their knowledge and excitement about ophthalmology research and clinical practice (question response rate: 100\% in 2016 and 73\% in 2017). When asked if students would recommend this course, 5/5 and 9/9 students who answered the question said "yes" in 2016 and 2017, respectively, (question response rate: $100 \%$ in 2016 and $82 \%$ in 2017). Finally, 5/5 and $8 / 8$ believed that the laboratory and discussion sessions where effective (question response rate: $100 \%$ and $73 \%$ in 2016 and 2017, respectively; - Table 3). After analyzing the free-comment questions, 12 students had comments related to general recommendations for the course. Five of those students suggested to work on time management, as some lectures went above the limited time. Three of the students suggested the addition of formal shadowing and research opportunities in our course. One student suggested the elimination of mandatory attendance, while another student recommended the addition of the course to the regular medical school curriculum. Another identified category based on the students' remarks was comments about the wet laboratory session. A total of 12 students had comments related to this session. In this category, three students suggested more wet laboratory experiences. Other students mentioned that the session was an effective use of time. A couple of students indicated that this session increased their knowledge about the anatomy of the eye. Four of the students characterized the wet laboratory session as fun and described the session as their favorite part of the course. To improve the wet laboratory experience, one student suggested to include a session on how to do microsutures. Furthermore, a total of nine students had comments about the journal discussion sessions. Among those, four students mentioned that the journal articles were challenging or went beyond their current ophthalmology knowledge. Five students, including three of the students above, mentioned that the facilitators did a good job in guiding and discussing the articles in detail. A couple of those students recommended more guidance when discussing the papers, including a template or power points to guide discussions. In this section, one student also commented on the benefit of learning about "cutting-edge technologies in the field" during these sessions. One student suggested limiting the sessions to one or two strong papers. Ten other students had comments associated to the overall curriculum content. Eight of those students mentioned that the course increased their knowledge and/or interest in ophthalmology and eye pathology. In addition, four of those students mentioned that the course was an excellent supplement to the material covered on the regular medical school curriculum. One of the students mentioned that some of the basic science lectures went into too much detail. Finally, a total of eight students had comments related to the combination of basic and clinical science of our course. Five of those students indicated that the course increased their knowledge about the research being conducted in the field of ophthalmology. The students also commented on enjoying the interplay between basic and clinical science. In this category, one of the students also recommended to focus more on the clinical science aspect. Some examples of the specific comments included: "I learned a lot about the eye I would not have known if I had not taken the course," "I enjoyed the interplay between the clinical and basic science experts," and "I liked the model of learning about a subject then looking at the research [sic]."

\section{Constructive Feedback}

The students pointed out the use of more interactive sessions, such as more wet laboratory sessions and clinical

Table 3 Responses to qualitative survey portion of survey

\begin{tabular}{|l|l|l|}
\hline & $\mathbf{2 0 1 6}(\boldsymbol{n}=\mathbf{6})$ & $\mathbf{2 0 1 7}(\boldsymbol{n}=\mathbf{1 1})^{\mathbf{a}}$ \\
\hline Would you recommend this course? & Yes $(5 / 5)$ & Yes $(9 / 9)$ \\
\hline $\begin{array}{l}\text { Did the course increase your knowledge and excitement about } \\
\text { ophthalmology research and practice? }\end{array}$ & Yes (5/5) & Yes $(8 / 8)$ \\
\hline Did you think the laboratory and discussion sessions were effective? & Yes (5/5) & Yes $(8 / 8)$ \\
\hline
\end{tabular}

${ }^{\mathrm{a}}$ Not all enrolled students responded the questions. 
experiences to get familiar with ophthalmology instruments. Additionally, the level of knowledge needed for the journal discussion sessions was thought to be too advanced. Some students believed that the elimination of mandatory attendance would allow them to focus on the required curriculum when needed, especially during examinations. Careful timing of lectures to prevent them from exceeding the allotted time was a common concern.

\section{Discussion}

Our ophthalmology elective was successful at giving more exposure to the field to 1 st and 2 nd year medical students. The students also perceived that the elective course increased their ophthalmology knowledge and enhanced their interest in pursuing a career in the field.

Among the lecture formats offered by the ophthalmology elective course, the interactive dissection portion was particularly well received among students. This is consistent with interventions at other programs that show that multiformat and interactive lectures enhance learning outcomes and student satisfaction. For example, a multimedia interactive module offered at Queen's University School of Medicine in Ontario that reported higher composite scores on multiplechoice ophthalmology questionnaires. ${ }^{15}$ On the other hand, an elective offered at Duke University that reported high levels of satisfaction after developing an interactive method for teaching eye and orbit anatomy during one of their ophthalmology rotation. ${ }^{16}$ Additional interventions at other programs, such as St. Matthew's University, Vanderbilt University, and other programs in the United Kingdom, have shown similar results in their respective fields. ${ }^{12,17,18}$ Interestingly, a study showed that even one ophthalmology day is able to improve ophthalmic knowledge and eye examination skills in medical students. ${ }^{9}$ Thus, we believe that in the future, our elective will have similar impact in students in terms of increased ophthalmology knowledge as well as interest in the field. We expect to see these results through longitudinal follow-up of our students.

On the other hand, the students' constructive feedback allowed us to see that timing and length of the elective's sessions are key factors for student satisfaction. The students also believed that some of the journal articles presented were difficult to understand. To address the students' concerns, and for future classes, modifications to the course included limiting presentation time, simplifying presentation topics based on recommendations from the Association of University Professors of Ophthalmology, and by providing a worksheet to guide article review. In addition, based on the students' feedback, the course directors decided to expand the course to 1 st year medical students in addition to 2 nd year medical students. We believe that these changes will improve our elective's outcomes.

It is well established that basic science research in ophthalmology has led to significant advances in the understanding and treatment of ocular diseases. ${ }^{19}$ Examples of these include Anti-vascular endothelial growth factor (VEGF) therapy of agerelated macular degeneration, RPE65 gene therapy for Leber's congenital amaurosis and other therapies to treat autoimmune and neurodevelopment conditions. ${ }^{20-23}$ Therefore, the importance of collaboration between basic scientists and clinicians has become key for the advancement of ophthalmology. It is important to note that the collaboration between practicing physicians and researchers in the field played a fundamental role in the development and implementation of our elective course. As a result, our course allowed students to bridge the gap between these two ophthalmology disciplines. Moreover, the students believed that the early interaction with ophthalmology faculty was beneficial and allowed for more mentorship and research opportunities. These two components have been shown to play a fundamental role in ophthalmology residency matching. ${ }^{24}$

While the goal of our study was to present the students' evaluation of our elective course, it is important to note that the success of the course was solely measured based on the participants. As such, our study can be subject to survey bias. To address this, a pre- and postcourse knowledge-based assessment could be implemented for further cohorts. The possible inherent interest in ophthalmology of our students, as well as our small sample size, may present other potential limitations for our analysis.

\section{Conclusion}

In conclusion, our ophthalmology elective was successful at enhancing exposure to ophthalmology in the preclinical years of the medical school curriculum, while also allowing students to learn about careers as clinician-scientist. Therefore, we believe that programs, such as this one, have the potential to enhance the interest of valuable students in our field, as well as to increase ophthalmic knowledge and competency, regardless of the student's field of choice. Further studies would be needed to specifically address the direct impact of ophthalmology electives in ophthalmic knowledge retention and recruitment to our field.

\section{Presentation Declaration}

This represents original work presented at the Association of University Professors of Ophthalmology Annual meeting in Austin, TX, on January 26, 2018, during the Medical Student Education Paper Session by author J.S.

\section{Funding}

Challenge Grant to the Department of Ophthalmology from Research to Prevent Blindness, New York, NY.

Conflict of Interest

None declared.

\section{References}

1 Quillen DA, Harper RA, Haik BG. Medical student education in ophthalmology: crisis and opportunity. Ophthalmology 2005; 112(11):1867-1868

2 Kalina RE, Van Dyk HJ, Weinstein GW. Ophthalmology teaching in medical schools. J Med Educ 1981;56(02):143-145 
3 Mottow-Lippa L. Ophthalmology in the medical school curriculum: reestablishing our value and effecting change. Ophthalmology 2009;116(07):1235-1236, 1236.e1

4 Baylis O, Murray PI, Dayan M. Undergraduate ophthalmology education - A survey of UK medical schools. Med Teach 2011; 33(06):468-471

5 Shah M, Knoch D, Waxman E. The state of ophthalmology medical student education in the United States and Canada, 2012 through 2013. Ophthalmology 2014;121(06):1160-1163

6 Roberts E, Morgan R, King D, Clerkin L. Funduscopy: a forgotten art? Postgrad Med J 1999;75(883):282-284

7 Jacobs DS. Teaching doctors about the eye: trends in the education of medical students and primary care residents. Surv Ophthalmol 1998;42(04):383-389

8 Lippa LM, Boker J, Duke A, Amin A. A novel 3-year longitudinal pilot study of medical students' acquisition and retention of screening eye examination skills. Ophthalmology 2006;113(01):133-139

9 Quillen DA, Cantore WA. Impact of a 1-day ophthalmology experience on medical students. Ophthalmology 2006;113(12): 2307-2309

10 Tong L, Lee-Poy M, Maclver S, McAlister C. Eye Day for medical students: delivering ophthalmic undergraduate education through interprofessional collaboration. Can J Ophthalmol 2016;51(04): 242-243

11 Albert DM, Bartley GB. A proposal to improve ophthalmic education in medical schools. Ophthalmology 2014;121(06):1157-1159

12 Zuckerman SL, Mistry AM, Hanif R, et al. Neurosurgery Elective for Preclinical Medical Students: Early Exposure and Changing Attitudes. World Neurosurg 2016;86:120-126

13 Mummareddy N, Mistry AM, Thompson RC, Zuckerman SL. Neurosurgery Elective for Preclinical Medical Students: 6-Year Followup. World Neurosurg 2018;110:504-505
14 Lin H, Ouyang H, Zhu J, et al. Lens regeneration using endogenous stem cells with gain of visual function. Nature 2016;531(7594):323-328

15 Steedman M, Abouammoh M, Sharma S. Multimedia learning tools for teaching undergraduate ophthalmology: results of a randomized clinical study. Can J Ophthalmol 2012;47(01):66-71

16 Kivell TL, Doyle SK, Madden RH, Mitchell TL, Sims EL. An interactive method for teaching anatomy of the human eye for medical students in ophthalmology clinical rotations. Anat Sci Educ 2009; 2(04):173-178

17 Chan LK, Ganguly PK. Evaluation of small-group teaching in human gross anatomy in a Caribbean medical school. Anat Sci Educ 2008;1(01):19-22

18 Kerby J, Shukur ZN, Shalhoub J. The relationships between learning outcomes and methods of teaching anatomy as perceived by medical students. Clin Anat 2011;24(04):489-497

19 Stahl A, Smith LE. An eye for discovery. J Clin Invest 2010;120(09): 3008-3011

20 Adamis AP, Shima DT, Tolentino MJ, et al. Inhibition of vascular endothelial growth factor prevents retinal ischemia-associated iris neovascularization in a nonhuman primate. Arch Ophthalmol 1996;114(01):66-71

21 Maguire AM, Simonelli F, Pierce EA, et al. Safety and efficacy of gene transfer for Leber's congenital amaurosis. N Engl J Med 2008; 358(21):2240-2248

22 Caspi RR. A look at autoimmunity and inflammation in the eye. J Clin Invest 2010;120(09):3073-3083

23 Quiroga RQ Reddy L, Kreiman G, Koch C, Fried I. Invariant visual representation by single neurons in the human brain. Nature 2005;435(7045):1102-1107

24 Grubbs JR Jr, Mian SI. Advising Students Interested in Ophthalmology: A Summary of the Evidence. Ophthalmology 2016;123 (07):1406-1410 